\title{
Effect of Motivational Incentives on Staff Turnover in Hotel Industry in Gombe State
}

\author{
Babangida Mohammed Musa, Ibrahim Ahmed and Abubakar Bala \\ Department Of Business Administration Gombe State University, Gombe, P.M.B. 127, Gombe, \\ Gombe State, Nigeria.
}

\begin{abstract}
This study examined the effects of motivational incentive and staff turnover in hotel industry in Gombe state, Nigeria. A stratified random sampling technique was adopted in selecting 45 respondents from three (3) hotels across the state. Findings revealed that promotion, salary/wages, payment of leave benefits, career development/in-services training and work-hours impacts significantly on labour turnover. The study recommended among others that comprehensive incentives should be put in place by management to reduce labour turnover and ensure workers retention in the hotel industry in Gombe state, in particular and Nigeria in General.
\end{abstract}

\section{Introduction}

In a typical organizational working environment, it is imperative for organization to retain staff and ensure their effectiveness. Organizations are always established to achieve specific goals (Katz and Kahn, 1978) and such goals are tied to various degrees on staff motivation, retention, and efficiency among other things. Corporate entities especially in the hotel industry are facing a lot of problems in workers turnover and effectiveness (Agba, 2010). Despite the centrality of motivation as a vital tool in workers turnover and productivity, it is often underutilized by most managers in workplace (Agba, in Bassel et al, 2009).

Employing staff is important in any organization but their relation and productivity is even the most important. In Nigeria today, instead of providing the means by which workers are encouraged (motivated) and retained for effective performance, workers are deprived of their physiological needs through salary insecurity, delay in the payment of salaries and facing benefits and this have consequences in their productivity and motivation. Therefore there is need to examine the effects of motivational factors that would ensure workers efficiency and retention as well as service effectiveness in hotel industry in Gombe state, Nigeria.

\section{Biography Of Gombe State}

Gombe state is located in the northeastern part of Nigeria, is one of the country's 36 states, its capital is Gombe. The boundaries of the state roughly correspond to those of the Gombe Emirate, a traditional state.

The state nicknamed 'Jewel in the Savannah', was formed in October, 1996 from part, of the old Bauchi state by the Abacha military government. Being it located in the north eastern zone, right within the expansive savannah allows 'the state to share common borders with the state of Borno, Yobe, Taraba, Adamawa and Bauchi. The state has an area of $20265 \mathrm{~km}^{2}$ and a population of around 2,253,000 people as of 2006 census Gombe has two distinct climates, the dry season (November - March) arid the rainy season (April-October) with an average rainfall of $850 \mathrm{~mm}$. The state has 24 House of Assembly members. Gombe has 11 local Government Areas and 14 emirates/chiefdoms. It has 3 senators and 6 members in the national assembly.

\section{Administrative Division}

Gombe is divided into 11 local government areas

They are

\begin{tabular}{|l|l|l|l|l|}
\hline LGA & Area $\left(\mathbf{k m}^{2}\right)$ & Census 2006 population & Administrative Capital & Postal Code \\
\hline Akko & 2,627 & 337,853 & Kumo & 771 \\
\hline Balanga & 1,626 & 212,549 & Talasse & 761 \\
\hline Billiri & 737 & 202144 & Billiri & 771 \\
\hline Dukku & 3815 & 207190 & Dukku & 760 \\
\hline F/kaye & 1415 & 236,087 & Bajoga & 762 \\
\hline Gombe & 52 & 26 SOOO & Gombe & 760 \\
\hline Kaltungo & 881 & 149805 & Katungo & 770 \\
\hline Kwami & 1787 & 185298 & Malam Sidi & 760 \\
\hline Nafada & 1586 & 138,185 & Nafada & 762 \\
\hline Shongom & 922 & 151520 & Boh & 770 \\
\hline Yamaltu & 1981 & 255248 & Deba & 761 \\
\hline
\end{tabular}

Source: 2006 Census 
Gombe is mainly populated by Fulani people.

\section{Demographics}

\section{Literature Review}

Labour turnover refers to the movement of employees in and out of a business. However, the term is commonly used to refer only to 'wastage' or the number of employees leaving (Riley, 2012). It refers to the number of persons leaving and the ones retained within the organization. In most formal organizations, labour turnover is inevitable. Analysis of associates leaving the organization provides the data for staff supply forecasting, so as to calculate the number of workers lost who need to be replaced. More significantly however, the analysis of the number of associates who left the organization and the reasons why provides a guide to job retention policy/decision (Armstrong, 2004). According to Kohn (1993) and Logan (2008) in (Agbi, 2010), most workers leaves their workplace for another in search for more pay in form of salary or wages and other fringe benefits. They also leave in search for better condition of service, and career prospects. Others leave because of poor relationship with management and fellow colleagues and harassment by managers.

\section{Motivation And Turnover}

The term motivation is derived from o Latin word 'movere' which means to move (Dhameja, 2009). It means influencing workers behaviour to achieve organizational goals and objective. It determines whether an employee will do his job properly. Motivation increases workers performance. Pay, punishment or praise are external incentives or motivational factors that need to be internalized in order to become effective. Internal incentives on the other hand, are ego needs of the employee. It includes job satisfaction, job accomplishment and prestige (Dhameja, 2009).

Incentive guides activity in the direction of the goal. Monetary incentive includes rewarding workers for excellent job performance through opportunities such as training, flexible work hours, favourable work environment among others.

Motivation is a psychological process. A recent data-based comprehensive analysis concluded that competiveness problems appear to be largely motivational in nature (Mine, Ebrahim, and Watchel, 1995). Along with perception, personality attitudes, and learning, motivation is a very important element of behavior. Nevertheless, motivation is not the only explanation of behaviour. It interacts with and ads in conjunction with other cognitive processes. Managers today are using work environment as a means of effectively improving workers performance (Robertson, 2006). They are also using monetary and non monetary incentives to foster staff retention and effectiveness (Kepner, 2001). Monetary and non-monetary incentives are both critical in staff turnover and productivity (Nelson, 1999; Kepner, 2001). Motivation is something that can come and go in an instant. The workplace often can be a fun and enjoyable place, but other time can be a pit of hell. Motivation is delivered in many different ways. Each person may be different, but sometimes we share the same types of motivation with Luthans (1998) asserts that motivation should not be thought of as the only explanation of behavior since it interacts with and acts in conjunction with other mediating processes and with the environment. Like other cognitive process, motivation cannot be seen. All that can be seen is behavior, and this should not be equated with causes of behavior (Luthan, 1998).

While recognizing the central role of motivation, Evans (1998), states that, many recent theories of organizational behavior find it important for the field to reemphasize behavior. Lutham (1998) defines motivation as a "process that starts physiological deficiencies or need that activates a behavior or a derive that is aimed at a goal incentive". A simple definition of motivation is the ability to change behavior. If is a derive that compels one to act because human behavior is directed towards some goals.

Motivational incentives are key important because most employees leave their job to another for better pay or greener pastures. Workers may stay if their skills are fully utilized and are contributing to the achievement, of the overall goal of the organization. If employee's retention and productivity is base fundamentally on monetary incentive small business in the hotel industry would eventually lose their staff (Kohn, 1993). Limited work force in some specialized areas such as information technology, hotel management, accounting and auditing may contribute to workers' turnover. This is because there is high demand in the public and private sectors for workers in these areas. And since supply is insufficient the best bidder takes the day, and when another high employer comes up, the former employers lose their staff. This means that, for any employer to survive under such environment, aggressively recruitment and retention strategies are imperative. These strategies have to eliminate unwanted turnover (Madison, 2002). Job retention and productivity can also be achieved through adequate flow of information from management to workers and vice visa. Ongoing changes in the workplace require that managers give continuous attention to those factors that influence worker behavior and align them with organizational goals. No one theory is appropriate for all people and for all situations. Each individual has his own or her own values and differing abilities. In business settings, managers apply motivation theories to influence employees, improve morale and implement incentive and compensation plans. 
Career development is also a motivational incentive that promotes workers retention and productivity. Career development involves concerted efforts directed towards assessing a worker's potentials identifying likely career paths for that employee and designing and implementing various types of in-services training and experience to prepare that person for more advanced responsibilities. In most firms, it is becoming increasingly evident that career management programmes are cost justified in the same terms as starting programmes; that is each approval contributes to improved utilization of workers overall organizational utilization and growth (Leach, 1980). The purpose of career development is therefore to match an employee's career aspirations' with opportunities and challenges available within the organization. The interest of career development also entails a successful placement of employees in positions that meet their needs as well as organizational needs. Thus, employee career development must be of great concern to management in formal organizations (Gambill, 1979, Fillip, 1980). Employee career development; is directly related to organizational effectiveness and can also lead to more committed workforce and labour retention (Hall, 1976). Also Stevens et al (1978), opined that too much time in one position may be perceived as career stagnation and have an adverse effect on commitment and staff retention.

\section{Staff Effectiveness And Incentives To Motivate Employees}

Incentive is an act of promise for greater action, it is also called as a stimulus to greater action. Incentive are something which are given in addition to wages, it means additional remuneration or benefit to an employee in recognition of achievement or better work. It provides a spur or zeal in the employees for better performance. It is a natural thing that nobody acts without a purpose behind. Therefore a hope for reward is a powerful incentive to motivate employees. Beside monetary incentive there are other stimuli that can drive a person to do better. This will include job satisfaction, job security, job promotion and pride for accomplishment, therefore incentives really can sometimes work to accomplish goals of a concern. The needs for incentive can be many:-

1. To increase productivity

2. To arouse a stimulus work

3. To enhance commitment in work performance

4. To psychologically satisfy a person which leads to job satisfaction.

5. To shape the behavior or outlook of subordinate towards work.

6. To get the maximum of their capabilities. So that they can exploited and utilized maximally.

Managers the world over are constantly searching for motivational variables that would enable workers to perform at optimal levels to accomplish organizational goals. They are using monetary and no it monetary incentives to ensure employed effectiveness at workplace (Ushie, Agba, Agba and Best, 2010) staff effectiveness includes goal attainment, willingness to carryout assigned duties, contentment with the job, creativity and discovery, increase in productivity and selflessness (Onyene, 2000). There is a functional relationship between motivation and workers' effectiveness (Armstrong, 2004). There is a significant relationship between workers effectiveness and salary or money (Holley, Jennings, and Woltcrs, 2005). Salary serves as a vital system of reward or recompense in an organization and a source of staff motivation (Inyang and Akpama, 2002; Imafidon, 2003). Money is a form of pay or remuneration, and obvious intrinsic rewards as well as carrot that most workers want (Armstrong, 2004). The efficacy of salary as motivational factors was doubted, while the lack of it causes dissatisfaction and staff ineffectiveness, the provision, does not result in lasting motivation and satisfaction (Herzberg and Sinderman, 1957). Salary fringe benefits etc (monetary incentive) are secondary motivators for job effectiveness, human relations, prestige, recognition and achievement are primary motivators for workers efficiency (Satrivastava, 1994).

Staff effectiveness can be enhanced through management policies that ensure proper promotion of associates. Promotion (a non-monetary incentive) refers to advancement of a worker to a high job, which is better in terms of responsibilities, status, prestige, and salary than the former. Promotion is one of the ways of recognizing and developing abilities of workers for effective job performance. To enhance performance of workers, the income promotion and other benefits enjoyed by their colleagues in other profession must be assured. Except this is done the morale of such workers will fall, and this could lead to high job turnover (Akpamma, 2000). The work environment: plays significant role in workers effectiveness (Robertson, 2006). The availability arid prudent management of" the work environment determine the product and services of an organization as well as its staff performance or effectiveness (Mbipom, 2001; Apka, 2001). Training of staff constitutes yet another non-monetary motivator. Training refers to a set of activities that, enables an employee to acquire more needed skills, knowledge and attitude for effective job per for malice. It enhances the performance of existing worker. This is because a worker who is motivated through training would lake his work very serious (Richard, Steer and Porter, 1979).

Communication is also a potent tool for management effectiveness. It is inevitable tool for cooperative activity; motivation and coordinating units within an organization (Keper, 2001), Furthermore, there is a positive relationship between employee recognition (non-monetary incentive) and staff effectiveness (Sexby, 2002). 
Motivating workers for effective job performance through adequate recognition includes among others, recognizing and praising employees as soon as an assigned task is completed. Recognizing employs staff small improvement a workplace and recognition of other emotional needs of employees in and outside the workplace (Kepner, 2009).

\section{Theoretical Consideration}

The study adopted at least two theories to explain factors that affect workers effectiveness, job satisfaction, commitment and turnover. These theories are Frederick Herzberg - Hygiene theory, Abraham Maslow's Hierarchy of needs theory. The hygiene theory is based on the analysis of the interviews of 200 engineers and accountants in Pittsburgh United States of America. According to the theory employee needs are of two types: the hygiene factors which include supervision, interpersonal relations, working conditions and salary. The animal needs can act as demotivators but if satisfactory their motivational effect is limited (Cole, 1990). The Human needs (motivators) are recognition, work, responsibility and advancement (Etuk, 1991). The major difference between the two is that motivators bring positive satisfaction and effective performance of workers. However, hygiene factors do not positively promote good health, but can act to prevent ill-health in the workplace (Cole, 1990). Hygiene factors impede dissatisfaction but they do not lead to satisfaction; they bring motivation up to a -theoretical level zero, thus a necessary floor to prevent dissatisfaction and lake off point for motivation (Armstrong, 2004). The major conclusion of Herzberg was that money was not a motivator. This theory enables the study to look at factors such as achievement, advancement, recognition and responsibility and impacts on workers' turnover. The major setback of this theory is that it fails to recognize money as a motivator. While Maslow theory was adopted to complement the former, lie (Maslow) proposed that there are five (5) human needs that, they are arranged in hierarchy of prepotency as follows:

1. Physiological needs: basic need for food, air, water, rest etc.

2. Safely needs: needs for safety and security.

3. Social needs: needs for attention, belongingness and membership.

4. Self actualization needs: the needs to realize one's potentials and self fulfillment.

5. Esteem need: recognition.

This theory emphasized that as one level of need is satisfied, it cease to be a motivator. Another central point is that, people tend to satisfy their needs systematically, from physiological and then move up the hierarchy (Cole, 1990, Etuk, 199 If. Physiological needs are satisfied through money or salary. It could be noted that while Herzberg play down the importance of money or salary as a motivator, Maslow recognized money as the factor of motivation, and the starting point for other needs to be met. However, once money meets the physiological needs and to some extent the safety needs it cease to be a motivator. Maslow theory however did not emphasize on the importance of leadership or management style as a motivating factors.

\section{Methodology}

Survey design was adopted in this study. It was used because it allows the study to objectively sample opinion from employees in the hotel industry in Gombe slate on factors that affects their retention turnover. According to Cohen (1980), Babbie (1986), survey design, uncovered dale, interpret, synthesize and establishes the relationship among variables. It is also used to study peoples' attitudes, feelings and opinions. This enables the study to get the true feelings of workers on motivation incentives that affects their turnover. The study also opted for the design because it involves the collection of data and accurate description of existing phenomena.

The research area consists of selected hotels in Gombe state, Nigeria. Purposive and stratified random sampling technique was adopted in selecting 45 respondents from 3 hotels. The three (3) hotels were selected from each senatorial district. A total of 15 respondents were selected from each hotel to ensure equitable distribution of participants. Data was elicited from respondents using questionnaire.

\section{Data Presentation Amd Analysis}

The data collected through questionnaires were analyzed and tested the hypothesis and interpreted. The percentage method and chi-square test of significant were used for testing the research hypothesis.

Table 1: Low pay of salary and fringe benefits lead to employee's turnover in hotels industries

\begin{tabular}{|l|l|l|}
\hline Responses & Score & Percentage \\
\hline Strongly agree & 27 & $60 \%$ \\
\hline Agree & 13 & $29 \%$ \\
\hline Disagree & 5 & $11 \%$ \\
\hline Total & 45 & $100 \%$ \\
\hline
\end{tabular}

Source: Field survey, 2013. 
The above table shows that $60 \%$ of the respondents strongly agreed that low pay and fringe benefits has relationship with employee's turnover, $29 \%$ agreed that labour turnover has relationship with low pay and fringe benefits. While only $11 \%$ disagree with the view.

Table 2: Poor relationship with management and fellow colleague lead to employee turnover

\begin{tabular}{|l|l|l|}
\hline Responses & Score & Percentage \\
\hline Strongly agree & 30 & $67 \%$ \\
\hline Agree & 11 & $24 \%$ \\
\hline Disagree & 4 & $9 \%$ \\
\hline Total & 45 & $100 \%$ \\
\hline
\end{tabular}

Source: Field survey, 2013.

The above result indicates that $67 \%$ of the respondents strongly agreed that poor relationship with management and colleague lead to employee's turnover in hotels industries. And 24\% agreed with the views. But only $9 \%$ of the employees disagree with the view.

Table 3: Motivation is a tool for influencing employees' performance

\begin{tabular}{|l|l|l|}
\hline Responses & Score & Percentage \\
\hline Strongly agree & 25 & $56 \%$ \\
\hline Agree & 14 & $31 \%$ \\
\hline Disagree & 6 & $13 \%$ \\
\hline Total & 45 & $100 \%$ \\
\hline
\end{tabular}

Source: Field survey, 2013.

The table reveals that $56 \%$ of the employees strongly agreed that motivation has relationship with employees' performance and $31 \%$ agreed with the idea. While only $13 \%$ disagree. This implies the majority are of the view that motivation help to improved employees performance.

Table 4: High pay, fringe benefit and other incentive influence employees' productivity

\begin{tabular}{|l|l|l|}
\hline Responses & Score & Percentage \\
\hline Strongly agree & 30 & $67 \%$ \\
\hline Agree & 12 & $27 \%$ \\
\hline Disagree & 3 & $6 \%$ \\
\hline Total & 45 & $100 \%$ \\
\hline
\end{tabular}

Source: Field survey, 2013.

The table above depicts that about $67 \%$ of the workers strongly agreed that high pay, fringe benefits and other incentive help to influence employees' productivity. About $27 \%$ of them agreed. While only $6 \%$ disagree. This shows that only the least number of the employee disagree.

Table 5: Conducive Working Environment and Monetary Incentive Influence on Employees Retention

\begin{tabular}{|l|l|l|}
\hline Responses & Score & Percentage \\
\hline Strongly agree & 32 & $71 \%$ \\
\hline Agree & 11 & $25 \%$ \\
\hline Disagree & 2 & $4 \%$ \\
\hline Total & 45 & $100 \%$ \\
\hline
\end{tabular}

Source: Field survey, 2013.

As can be seen from the above table, $71 \%$ of the respondents have strongly agreed that conducive working environment and monetary incentive has influence on employees, $25 \%$ agreed. But only $4 \%$ disagree. This shows that majority of employees are on strong view that conducive working environment has significant influence on retaining employees.

\section{Hypothesis Testing}

As earlier stated the hypothesis is tested using Chi-square. The testing of the hypothesis reveals whether to accept or reject the null hypothesis.

$\mathrm{X}^{2}=\underline{(0-\mathrm{e})}$

$$
\mathrm{e}
$$

Where

$\mathrm{X}^{2}=$ Chi-square 
$0=$ Observed value

$\mathrm{e}=$ Expected value/frequency

$0-\mathrm{e}=$ Differences between observed and expected value

Having computed the Chi-square $\left(\mathrm{X}^{2}\right)$, the result should be compared with critical table value to find critical value; the degree of freedom is calculated.

Where

$\mathrm{DF}=(\mathrm{r}-1)(\mathrm{k}-1)$ Where

$\mathrm{r}=$ row number

$\mathrm{k}=$ Column number

In testing the hypothesis 5\% (0.05) level of significance is chosen by the researcher.

\section{Decision Rule}

If the calculated Chi-square is greater than critical value, the null hypothesis will be rejected. However, if the chi-square value is less than the critical value, the null hypothesis will be accepted.

\section{Hypothesis}

Ho: Low pay of salary and fringe benefits has no significant relationship with labour turnover in hotel industries. Refer to table 1:

\begin{tabular}{|l|l|l|}
\hline Responses & Score & Percentage \\
\hline Strongly agree & 27 & $60 \%$ \\
\hline Agree & 13 & $29 \%$ \\
\hline Disagree & 5 & $11 \%$ \\
\hline Total & 45 & $100 \%$ \\
\hline
\end{tabular}

Source: Field survey, 2013.

From the above I able

$\mathrm{e}=\frac{27+13+5}{3}=\frac{45}{3}=15$

Chi-square calculation

\begin{tabular}{|l|l|l|l|l|l|}
\hline Responses & 0 & E & $0-\mathrm{e}$ & $(0-\mathrm{e})^{2}$ & $(0-\mathrm{e})^{2} / \mathrm{e}$ \\
\hline Strongly agreed & 27 & 15 & 12 & 144 & 9.6 \\
\hline Agreed & 13 & 15 & -2 & 4 & 0.26 \\
\hline Disagree & 25 & 15 & -10 & 100 & 6.67 \\
\hline Total & 45 & 45 & 0 & 248 & 16.53 \\
\hline
\end{tabular}

The $\mathrm{X}^{2}=16.53$

$\mathrm{DF}=(\mathrm{r}-1)(\mathrm{k}-1)$

$=(3-1)(2-1)$

$=(2)(1)$

$=2$

From the Chi- square table DF of 2 under $0.05=5.991$

From the above table, the calculated chi- square is 16.53 and the critical table value is 5.091. Since the calculated Chi- square

value of 16.53 is greater than the critical table value of $5.991(16.63>5.991)$. Reject the null hypothesis, that is low pay of salary and fringe benefits has significant relationship with labour turnover in hotels industries.

\section{Conclusion And Recommendation}

The frequency of labour turnover in the hotel industry in Gombe state is quite revealing. We can deduce from this study, that there exists a linear relationship between salary/wages, worker development, fringe benefits, promotion work-hours and labour turnover in the hotel industry in Gombe state, Nigeria. It is seen clearly, however, that the frequency of labour turnover is affecting the overall organizational goal attainment. "The commercial nerve centre of the north eastern sub-region" which drive the business activities of the state will be impeded if" nothing is done to salvage the precarious situations in the hotels industry of the state, in the strength of the above, we recommended that monetary and non-monetary incentives should be put in place in the hotel industry in Gombe State to reduce the high rate of labour turnover; this could also enhance workers commitment, retention and services delivery in the industry.

\section{References}


[1] Agba, A.M. (2004) Teachers' perception on their job performance. Unpublished postgraduate thesis on Education of I he University of Calabar.

[2] Akpar), C.P (2001). Strategies for sustainable management of school physical facilities in 21 st century. An international journal of Educational Administration, planning and research, 1(10: 80-86.6).

[3] Armstrong, M. (2004) Human Resource Management practice (9"' edition) London: Kogan page. 11.

[4] Babbie, E. \{1986). The Practice of social Research Carlifoiiia: Wadsworth .1 2) Bassell, i.

[5] Kepner, K. (2009) Understanding Motivation: An Effective Tool for Managers. (Online), available; hUp//cdis.ifas.ed/\#KOl7.

[6] Slum, M.L (2004) Industrial psychology: Us Theoretical and social foundations. New Delhi. CBS publishers and Distributes.

[7] Jones, P. (1992) Managing Organizations in Africa. New York: Walter dc Gruyier.Cohen, A. and Manion, L. (1980) Research method in Education. London: Croon Helm.

[8] Dhameja, S.K and Dhameja, S. (2009), Industrial psychology New Delhi. S.K Kataria and sons.

[9] Flippos, E.B. (1980) Personnel management. Koan Kushai McGraw-Hill. Synderrnan, B (1.957). The motivation to work. New York: Wiley.

[10] Jennings, K. M. (2005). The labour Relations process. (8th Edition). Inyan, B.J. and Akama, A.M. (2002). Personnel Management Practice in Nigeria Calabar: Kphraim Printers.

[11] Katz, D. and Kahri, R. L. (1978). The Psychology of Organizations, New York: John Wiley.

[12] Kepner, K.W. (2001). Human resource Management in Agribusiness online) available: hltp//www. Keepemployees.com/retention.

[13] Richard, N. arvd Porter, L.W. (1979(. The measurement of organizational commitment. Journal of vocational Behaviour,14, 224-247:50).

[14] Onyene, V.E (2000), Dynamics of institutional management: towards strategic administrative competence. Lagos: Samoncnt publishers.

[15] Madison, G.H. (2002). Employee retention On report of the employee retention work group (online). 